\title{
2
}

\section{Multi-level Governance and the Study of Australian Federalism 1}

\author{
Adrian Kay
}

\section{Introduction}

The concept of multi-level governance (MLG) has yet to gain wide currency in either public or academic discussion of policymaking in Australia (important exceptions are Painter 2001; and Gleeson 2003). Although, as an academic term, MLG is now 20 years old, much of the practice and process in multi-level systems that it labels are far older. Emerging originally in the study of the European Union (EU), MLG is particularly linked to the EU regional policy framework where new policy and administrative territorial spaces have been created, often overlapping existing national and sub-national boundaries. This is part of the 'Europe of the Regions' project, in turn linked to discussions of the 'new regionalism' in which contemporary geo-economic processes have putatively restructured the spatial scales of effective economic policymaking away from the national level to simultaneously the global and the regional/ local levels (e.g. Gleeson 2003). The distinctive governance features of EU regional policy are that the European Commission deals directly with the novel territorial jurisdictions rather than through member-state

1 This chapter is a republication (with permission and with minor adjustments) of the paper: A. Kay (2015). Separating Sovereignty and Sharing Problems: Australian federalism and the European Union. Australian Journal of Public Administration, 74(4): 406-18. 
governments as intermediaries and these interactions generally operate without a hierarchy, are relatively informal in character and, in the most effective cases, are based on a shared commitment to problem-solving.

The MLG concept is not faddish. It remains immediate and relevant to understanding contemporary processes of European integration, well beyond its origins in regional policy. For example, the transformation of economic governance in the EU between 2010 and 2015 following the sovereign debt crisis; the rescue packages for Ireland, Portugal and Greece; and the European Financial Stability Facility, the Euro Plus Pact, and the Fiscal Compact Treaty ${ }^{2}$ all amount to an expansion of EU-level powers at the expense of national fiscal autonomy - powers that were previously jealously guarded. The issuing of EU-backed bonds and the establishment of a rescue fund apparently contravenes the 'hard' constitutional rules of the EU budget. In fiscal federalism terms, while the member-states remain at the centre of analysis, they have delegated finance powers - limited in scope but large in potential size - upwards to the larger, EU level in response to a policy challenge that is only surmountable at the Eurozone spatial scale. Whilst collectively the changes have had a significant impact on European economic governance, not all of the measures formally belong to the EU.

The MLG concept has merit in gaining leverage in the case of sovereign debt crises because it places experimentation and innovation in policy coordination across different spatial levels at its analytical core. It is possible to abstract from governance changes observed in the EU context to cast light on experiments in creating cross-jurisdictional policy capacity in Australia, across and between different governance jurisdictions to match the territorial scale that is functional for effective policy response. In such terms, this chapter argues that the MLG concept can contribute to the analytical value of the concept of 'pragmatic' federalism in Australia that is advanced by Hollander and Patapan (2007), in which there is a dynamic within federalism that allows it to adjust to changes in the territorial scales of policy problems.

As an indication of its value as a label for a core aspect of EU policymaking, the MLG concept has crossed the academic-practice boundary. Several institutions of the EU, in various prominent documents, have talked

2 Colloquially known as the Fiscal Compact Treaty, its full title is: Treaty on Stability, Coordination and Governance in the Economic and Monetary Union. 
about methods or modes of 'doing' MLG (e.g. European Commission 2001; Committee of the Regions 2009). Even though the practice of MLG in Australia long predates its conceptualisation in the EU, there is advantage in applying the term in Australia. Notably, it facilitates a selfconscious reflection on both examples of experimentation and innovation in multi-level interactions within the settled constitutional boundaries of the federation, as well as cases where the policy agenda is more sclerotic and reform efforts hamstrung by a divided polity. Such reflexivity can help provide a novel thematic within venerable studies of Australian federalism and contribute to the analysis of changes in Australian fiscal federalism in response to the beginning and end of what former Treasury secretary Ken Henry has called the 'greatest external shock' in the history of the Australian economy - the mining resources boom and bust (Kelly 2010).

This chapter advances the argument that the MLG term can contribute to understanding the capacity for, and barriers to, dynamism and innovation in the Australian federation. This does not rely on an empirical comparison of the EU and Australia, but rather the advantages of placing the quality of the interactions between different jurisdictions at different spatial scales at the centre of analysis. Here the MLG concept serves both to complement and extend long-established seams of work on the constitutional allocation of competences between levels or analyses of the distribution of fiscal authority over revenue/expenditure. In particular, the chapter accepts the widely diagnosed centralising dynamic in Australian federalism as an enduring feature, but argues that a focus on the characteristics of harmonisation and coordination can sometimes obscure from view the potential for experimentation, variety and difference in multi-level policymaking in Australia.

The Reform of Federation white paper being developed in 2015 has the organising thematic that 'every level of government will be sovereign in its own sphere' (Abbott 2014). This is linked to well-rehearsed concerns about vertical fiscal imbalance that are being tackled in the tax white paper process running simultaneously. From an MLG perspective, the appeal to sovereignty is curious. There is nothing in the pragmatic history of Australian federalism to suggest constitutional answers to the shifting geographies of policy problems; indeed, the absence of seminal, big bang constitutional reforms is noteworthy. Sovereignty is a problematic concept in political theory and, although it is not for this paper to review the history of political thought on the question, we can state initially that sovereignty, in the sense of clearer constitutional roles and responsibilities, 
does not imply capability. To be sovereign is not the same as being functional in a public administration and policy sense, as the history of Australian federalism attests.

The EU has dealt with the problems of sovereign borders and the nature of policy problems that span many of these; indeed, it is, on many influential accounts, the motor of European integration. Similarly, it appropriated the concept of subsidiarity in parallel with the Council of Australian Governments (COAG) at the end of 1991. This chapter uses the concept of MLG to strike a sceptical note on both the desirability and feasibility of a big bang, once-in-a-generation reform of the federation. The capacity for shared, cross-jurisdictional policy coordination is not a neat function of constitutional design; far from it, the story of economic integration across territorial space shows the need for plasticity, innovation and adaptation as key aspects.

The following steps are taken in the chapter. The first defines the main elements of MLG and sets out what it may add to the existing understanding of Australian federalism and its reform. The next section considers the general characteristics of MLG observed in contemporary Australian federalism. The final section presents the open method of coordination (OMC) form of MLG as helping understand Australian fiscal federalism since the December 2008 Intergovernmental Agreement (IGA) on Federal Financial Relations, the structural changes in the economy brought about by the mining boom and subsequent bust, as well as the limitations of the current Reform of the Federation white paper.

\section{MLG: What is it? ${ }^{3}$}

The term multi-level governance was coined in Marks (1993: 392) to refer to 'a system of continuous negotiation among nested governments at several territorial tiers'. This has acted as a serviceable baseline definition to underpin subsequent refinements of the term that stress the nonhierarchical, informal and deliberative aspects of the negotiations under scrutiny (e.g. Hooghe and Marks 2001; Sabel and Zeitlin 2007). There

3 This chapter uses the MLG term analytically as an aid in understanding decision-making across different jurisdictional levels. However, Stein and Turkewitsch (2010) argue that there are (at least) two other distinct senses in which the MLG term is employed: (i) an empirical description of a specific governance form, particularly the EU; and (ii) normatively, to evaluate improvements in intergovernmental decision-making. 
is some variation in the MLG literature about the extent to which nongovernment actors need to be included for a process to be categorised as MLG. For example, Peters and Pierre (2004) stress the governance aspect in MLG, arguing that this introduces a potentially wider cast of policy actors than in conventional accounts of intergovernmental relations.

In this analysis, MLG is a subset of governance, and thus the distribution of authority and policy capacity sideways must be taken into account across different sectors and spheres, including states, markets and civil society, and not just on the vertical plane upwards and downwards. Hooghe and Marks (2001) distinguish between Types I and II of MLG. Federalism is the exemplar of Type I MLG, where authority is dispersed to a limited number of general purpose jurisdictions, which are stable across time and do not overlap. Type II MLG, in contrast, is characterised by fluidity with the potential for a patchwork of numerous overlapping jurisdictions. These often have single tasks rather than multiple and general purposes, and include explicitly and formally non-government actors. In addition, they are potentially short-lived, with their continued existence depending directly on the nature of the governance challenge they are established to confront.

This typological separation of MLG helps to sidestep the Peters and Pierre (2004) issue by broadening the scope of the concept: both government and governance interactions can be usefully located on both vertical and horizontal dimensions. In such light, MLG is revealed as a composite construction: it brings key governance insights from studies of nonhierarchical, informal and continuous interactions between public organisations into federal studies and, at the same time, it identifies a particular governance problem in federal systems - multi-level policy coordination - within broader governance debates. The manifest scholarly challenge is to conceptualise and explain the relationships between the relatively enduring Type I features of Australian federalism and Type II issue-based, territorially novel and often ephemeral policy responses to particular governing challenges.

Of course, the trade-off for broadening the scope of MLG with the Hooghe and Marks (2001) typology is a reduction in its analytical precision. If any governmental or governance process located on a vertical and horizontal dimension counts as MLG, what does the term add to our understanding? The answer for the study of Australian federalism is that its distinctiveness lies in the emphasis on policymaking and policy coordination across 
different territorial jurisdictions outside a formal, institutionally prescribed vertical order. The problematic nature of the vertical ordering of different levels or spatial scales of policy analysis distinguishes the MLG concept within that of governance more generally. The MLG concept serves to organise analysis of situations in which that vertical ordering is not neatly constitutional, because formal powers are concurrent or overlapping or simply ambiguous, but where there is a powerful vertical interdependence in the control of governing resources and policy instruments.

One persistent theme in the study of European integration is that EU multi-level policy coordination has been successful, even in the absence of a constitutionally prescribed, vertical order, because EU policymaking is, to a significant degree, deliberative and technocratic. The EU's enormous comitology structure of expert committees (whose membership is drawn from the EU institutions, member-states and sometimes outside organisations) has had the putative consequence of socialising different national and sub-national interests into a shared enterprise through regular and frequent discussion and sustained argument. This socialisation mechanism can lead to a problem-solving mode of policy coordination among policy actors representing different levels in which starting policy preferences are adjusted and adapted through reasoned debate. Although this mechanism has not been universally observed, evidence of its effect may be read in many fields from monetary union to environmental policy, where the EU has been able to move beyond simple intergovernmental bargaining in which progress is limited by the lowest and fixed common denominator policy preference.

MLG processes in the EU tend to be informal: the rules that govern them are tacit and uncodified rather than explicit; unofficial rather than official; and emergent and self-enforcing rather than purposely designed with a third-party enforcer. The central point in Types I and II of MLG is that order and policy coordination between levels cannot be read off or anticipated in formal legal instruments or constitutional provisions. Instead, MLG is a negotiated order. For some, this informality is the great advantage of MLG because it allows extra-legal workarounds to circumvent some of the blockages apparent in the EU's formal institutional design. 


\section{What does the concept of MLG add to the study of federalism?}

As an analytical term, there is the obvious challenge for MLG: to specify what it adds to the long-standing study of federalism in Australia. Two initial contributions can be identified. The first is to give the Australian constitutional grid a degree of policy dynamism in terms of trans-boundary agenda setting, the flow of different ideas, and the development of shared arrangements for feedback on policy performance. Notably, the concept allows the insight that these flows do not follow straight, constitutionally prescribed lines of transmission. For example, Brumby and Galligan (2015: 83) outline the benefits of 'healthy competition' between states and instances of policy mobility. Further, the New Zealand Government is a formal member of many coordination structures for intergovernmental relations - for example, the COAG Health Council - as is the president of the Australian Local Government Association. By giving a name to these kinds of processes, MLG serves to highlight potential sources of, and barriers to, institutional innovation in the Australian polity. In turn, this sets out a potential agenda for a seam of future research on Australian federalism. For example, the existing literature provides little on the relationship between intergovernmental processes and the socialisation of public servants from different jurisdictions towards a shared problemsolving perspective in Australia.

Second, MLG can be used to identify a variegated tendency within Australian federalism in the open economy era, in which analysis of policymaking that stresses distinctive sector-specific context and pathdependency, on the one hand, can be balanced adequately with common underlying tendencies towards centralisation on the other. Fenna (2009) reviews the seminal works on Australian federalism and, drawing on Sawer (1969) and Mathews $(1977,1982)$ in particular, sets out the distinct historical stages of coordinate, cooperative and integrated federalism through which Australia has passed. This periodisation is uncontentious (e.g. Hollander and Patapan (2007) draw similar epochal divides) and the general trajectory offered is familiar as a description of Australia's changing political economy: as national economic integration has deepened, so the Commonwealth has assumed increasing power, particularly in respect of control over taxation, to arrive at a situation where, as Sawer put it in the late 1960s, cooperative federalism is simply a euphemism for 
centralisation. In a widely expressed view, the upholding of the use of the corporations power $s 51(\mathrm{xx})$ in the WorkChoices case $\mathrm{e}^{4}$ indicates few legal limits on the Commonwealth's formal ability to reshape federalism.

Recent writing on Australian federalism, however, whilst not doubting the validity of this underlying narrative, has begun to offer more nuanced accounts of federalism after 1983 (see, for example, Carroll and Head 2010; Hollander and Patapan 2007; Brown 2007; Parkin and Anderson 2007; Keating and Wanna 2000). In these works, the process of centralisation is not unidirectional nor uniform across all policy sectors; Hollander and Patapan (2007) observe a 'pragmatic' federalism in Australia in which the federation has been continually reshaped by political dynamics to meet the policy demands of the day in the absence of an overarching political theory of federalism to inform party ideology and judicial policymaking. Within the political system, party allegiance no longer provides a reliable guide to federalism beliefs and the High Court has tended to see its role in terms of the particular disputes between parties rather than divining an overarching theoretical legal structure in Australian federalism. In such circumstances, pragmatist federalism bends and adapts according to the spatial scale of the policy challenges presented by particular circumstances in the political economy.

In response, Fenna (2012) argues that whatever the superficial attractions of the notion of a pragmatic federalism, it lacks a theoretical underpinning and therefore explanatory power. At best, the term offers a label for the mechanisms of intergovernmental adjustment but the challenge, for Fenna, is to articulate underlying general tendencies to centralisation in Australian federalism as well as account for observed sectoral variations in how pragmatic adjustments have played out in practice. The analysis in this chapter does not require a position on this criticism, instead it is sufficient to note that, if it holds at all, it pertains more broadly; there is an absence of a general theory of the dynamics of Australian federalism.

In this chapter, the pragmatic term is useful. It helps describe the characteristics of the development of COAG over 20 years or so into a permanent and standing body for the systematic organisation of intergovernmental relations (Carroll and Head 2010). Although the core executive of the Commonwealth Government exercises substantial

4 New South Wales v Commonwealth [2006] HCA 52; 81 ALJR 34; 231 ALR 1 (14 November 2006). 
influence and control in COAG, consistent with centralisation, for others its arrival and potential future development serves as a counterpoint to immanent centralising tendencies and offers renewed multi-level collaborative potential in the Australian federation (Kildea and Lynch 2010; Painter 2001; contributions in Brumby and Galligan 2015; CEDA 2014).

The core of the pragmatist insight is that the federalist structure remains intact as the locus of policymaking moves in a centralising or decentralising direction as appropriate to the territorial scale of the governance challenge at hand. But, if that capacity for adaptation to the political economic exigencies of its day is large, does federalism matter in a policymaking sense? The pragmatist reply is that theirs is not a structuralist account in which the exigencies of the international economy explain formal changes in the Australian federal system; instead, the process of adaptation requires an active process of governing across multiple levels and jurisdictions with attendant uncertainties and contingencies. The distinguishing feature of Australia as a federation is the constitutionally entrenched position of the states in policy areas where they enjoy formal powers concurrent with the Commonwealth, as compared to policy coordination in non-federal multilevel systems where lower levels can be more easily reorganised. The states are a potential veto player in the process of federalism adaptation because they enjoy, at least formally, the option of acting unilaterally.

The Commonwealth Government is ineluctably involved in nonhierarchical policy coordination. Even if it enjoys the advantage of highly asymmetrical bargaining power, it still relies on the willingness of state governments to enter and engage in a process of negotiation. It can obviously set financial incentives to achieve this, but each government maintains a formal, constitutional right to refrain from coordination, and the involvement of COAG in coordination processes does not make them 'hierarchical'. MLG acts as a label for the policy problem-solving dilemma peculiar to federal systems where formal competences are divided and governing resources distributed between jurisdictions, however unevenly, such that coordination cannot be centrally (or hierarchically) imposed on any of the participating governments.

In the abstract, different non-hierarchical modes of coordination to solve collective policy problems can be stated, ranging from mere policy emulation between and among different levels of government, to ad hoc coordination, to informal political agreements, to formally binding rules. 
To advance the contribution of the concept of MLG to understanding pragmatic federalism, two dimensions for organising non-hierarchical coordination in concurrent areas are salient in the MLG literature. The first dimension is the extent to which different governments are acclimatised to an interdependent policy environment; the second is the degree of institutionalisation of multi-level coordination.

At one end of the first dimension is the absence of coordination between levels, where each jurisdiction thinks and acts unilaterally. Further along the scale is a situation of mutual adjustment where, in the absence of any formal or informal agreement, each level takes the veto power of others into consideration in its policymaking but still acts unilaterally. Bargaining is further along still and refers to cases where actors from the different levels acclimatise to interdependence by being willing and able to enter a process of interaction and to adjust their interests in such a way that coordination becomes possible. The problem-solving mode sits at the opposite end of the scale to no coordination, standing analytically for a common-goal orientation in decision-making across levels, in which the individual interests that each level brings to the interaction are sublimated to a shared sense of the problem and solution.

The second dimension refers to variation in the institutionalisation of mechanisms for governing interaction across levels. Formal rules that compel negotiations across levels are prone to deadlock or may suffer Scharpf's (1988) famous 'joint decision trap', where the set of possible negotiating outcomes is limited to the lowest common denominator of starting-policy preferences. Where interaction across levels is not compulsory, however, there is the possibility of negotiation around principles and outcome-based standards for policy coordination. The $\mathrm{OMC}$, discussed below, pioneered in the EU, is the exemplar of this possibility. Patterns of interaction based on broad principles for shared approaches to policy coordination may iteratively build trust and facilitate a problem-solving mode of governance.

Carroll and Head (2010) trace a history of COAG as a prominent indicator of the problem-solving capacity in the Australian federation on the first dimension. In a 'golden age' of reform (Head 2007), the structures of Australian federalism that might retard progress were successfully overcome through the gradual development of networks, institutions and processes for cooperation across levels. This is an important MLG tendency within federalism in Australia; within which has notably been 
the construction of an organisational capacity for political leaders to lead and direct the evolving intergovernmental system (Painter 2001). In terms of the second dimension above, the norm in COAG is consensus with the option reserved by all states and territories not to sign up to an agreement. Painter (1998) points out that there has been majority voting in ministerial councils from the late 1980s onwards.

At the two special premiers' conferences in November 1991 that established COAG, subsidiarity was stressed as a foundational and guiding principle (Australian Government 2015). This is the principle that functions should be performed by the lowest level of government able to do so effectively. Intriguingly, for understanding the role of EU MLG dynamics in Australian federalism, this principle in the foundation of COAG was embedded at the heart of the EU only a few weeks later in 1991 in the governance of intergovernmental relations under the famous Maastricht Treaty (formally the Treaty on European Union). Like the EU, Australia had found, and continues to find, constitutional change hard; subsidiarity was a concept recovered from the history of the Catholic Church as a way of thinking about how these Type I structures can be compensated for or, at least, adapted and reinterpreted for Type II sets of dynamics.

Before 1990, intergovernmental relations were largely decentralised, with policy issues addressed in a compartmentalised series of councils and committees. Carroll and Head (2010) describe the slightly ad hoc and unsystematic nature of this system and argue that it was not fit for the purpose of major microeconomic reforms that came in the late 1980s and into the 1990s. They conclude that the continuing development of COAG has enhanced the effective management of intergovernmental relations and, in an example of problem-solving in MLG, increased Australia's policy capacity for strategic, general interest reform.

Whilst acknowledging COAG's achievements in policy reform, it remains ad hoc in many important respects and, in the absence of a firm legal or constitutional footing, COAG's operation and its agenda remains at the discretion of the prime minister of the day (Brumby and Galligan 2015; Kildea and Lynch 2010). For example, there has been significant variation in the number of times that COAG has been held, from less than once a year in the early years of John Howard's government to four times a year under former prime minister Kevin Rudd. An important related consequence of prime ministerial discretion is that COAG has a tendency to centralise policy control at the expense of diversity, thus 
losing the advantages of diversity and learning between states (Anderson 2008; Brumby 2009; Brumby and Galligan 2015). Similarly, running through the Senate Committee Report's (2011: 53) agenda for reform of the Australian federation is a stress on 'joint ownership' in negotiations among the Commonwealth and state and territory governments, particularly with the latter having greater input in setting the agenda of COAG. Perhaps the most striking example of COAG's institutional frailty and lack of an independent, enduring status is the introduction in 2008 and subsequent abolition in 2014 of the COAG Reform Council.

\section{Problem-solving in Australian conditions: Pragmatic diversity in changing economic geographies}

For Australian federalism to be pragmatic, there must be potential for processes that push back against centripetal tendencies immanent in the system in circumstances where the nature of the policy challenge demands decentralisation and diversity. For example, if effective policy coordination requires an agenda with significant input from beyond the centre, and a toleration of cross-jurisdictional diversity, under the pragmatist account we would expect to observe decentralising adaptations in Australia. The development of COAG over 20 years may have worked in the field of microeconomic reform at the national, economy-wide scale, however, there are contemporary policy challenges whose scalar components are not so straightforward and where it is not obvious that COAG's previous success in producing general interest economic reforms at the national level can be replicated without some changes in the MLG template.

Several seams of ongoing political economy study, such as that on 'variegated' capitalism (Peck and Theodore 2007), the new economic geography (Krugman 1998; Porter 1998) and 'spatial' Keynesianism (Brenner 2004; Eisenschitz and Gough 1996) all suggest that there is no single or temporally fixed jurisdictional scale that defines the most effective institutional basis for successfully coordinating policy in core areas of economic development such as labour markets, vocational training and skill development and entrepreneurship (Brenner et al. 2010; Peck and Theodore 2010; Gleeson 2003). 
The multi-level policy dilemma of the territorially uneven consequences of the Australian resources boom and bust is clear: a less uniform policy landscape and more adaptable fiscal federalism are required. The structural change resulted from the combination of rapidly improving terms of trade reversing a secular decline that has then unravelled as international commodity prices softened and Australia's terms of trade declined and investment in the mining sector fell. The multi-speed economy and attendant structural economic change presents a requirement for rethinking the scales of Australian public policymaking. Whilst this may be most readily apparent in fiscal federalism terms as the resources boom leads to significant changes in the states' net fiscal positions, there is an underlying catalyst: as the imperative of international competitiveness has become firmly embedded as a governing template, so public policy itself and the process by which it is made has become a factor in economic competitiveness (e.g. Campbell 2004).

This extends well beyond established debates about tax competition and internationally mobile capital to the main foundations of productivity: the quality of the microeconomic business environment. In a highly influential work, Porter (1998) argues that public policy has a prominent role here in areas such as training, infrastructure provision, procurement practice, locating airports and providing higher education services. Firms can derive competitive advantage from operating within an effective set of arrangements for multi-level policy coordination in these areas.

In Australia, the idea of public policy as a source of competitiveness has evolved distinctively. From its roots in the National Competition Policy and a focus on market regulation (Morgan 2003), the notion of policy competitiveness now envelops core human service delivery areas of government activity as well. In a related action, the Australian Government introduced a Commonwealth-wide Contestability Framework in the 2014-15 budget (Cormann 2015). Sectors that are conventionally seen in social policy terms, or at least involving some entitlement derived from social citizenship rights, are framed in the productivity agenda as an active ingredient of a competitive economy. In doing so, the appropriate territorial scale of policy action is refashioned as territorial equity and becomes less of a concern, replaced with the scales functional for economic policymaking and structural adjustment in a multiple speed economy characterised by a profound differential between resource and non-resource sector growth. 
These scales tend to be smaller and more variegated than the universalism of social welfare provision. The result is that in many policy areas in Australia, in which formal powers are concurrent and have characteristics of both economic and social policies, as the recently published Harper Competition Policy Review sets out, the multi-level policy coordination challenge is to rethink policy spaces for effective intervention and their effective interrelationship in a federal system (Commonwealth of Australia 2015).

\section{The open method of coordination}

The story of EU constitution-making is not one of settled or seamless progress but, rather, is marked by delay, deep-seated disagreements about the nature of la construction européenne, and populist success in defeating constitutional referenda. In response, the EU has been forced to develop new and creative forms of governance to meet the problems of multi-level policymaking without a constitutional state to provide vertical order. In such terms, the EU is an 'experimentalist' form of governance (Zeitlin and Sabel 2009), and one of its distinctive innovations is the OMC. In this form of MLG, bespoke institutions for multi-level policy coordination are established for particular policy challenges and agreed in advance by participating governments as able to be revised rather than being fixed.

These institutions contain relatively broad, open-ended policy objectives, and include an agreement on how to chart progress towards those objectives on a common measure. Critically, in multi-level policy coordination terms, lower-level jurisdictions enjoy substantial discretion in how to design and implement policy directed towards achieving those objectives. Under the OMC, this discretion comes with an extensive and public reporting requirement on progress towards the common objectives. This allows transparent comparison between the different jurisdictions pursuing different means to achieve the same shared goal. In theory, the result of this system is an iterative process of learning and deliberative problem-solving in which both the rules and goals are regularly revised based on the experiences of implementing them.

The intention of the OMC is that this learning can lead to a convergence of both policy agendas and the general direction of travel in performance, but not of specific programs, policy instruments or settings. This tolerance of diversity is a political sine qua non of EU multi-level policymaking in 
many fields; for example, the OMC has been extensively used in areas of employment policy where deep-rooted differences in national institutions and policy legacies have served to substantially limit opportunities for European-level harmonisation. The ambition to reconcile common EU-level action with legitimate national and sub-national diversity has become heightened with the enlargement of the EU to 27 members over the last decade, each presenting singular economic histories, labour market institutions and social welfare systems.

In Australia, the OMC model of MLG is useful for the analysis of adjustments in pragmatic federalism. The increasing diversity and unevenness in the economic geography of Australia demands a recovery of the early policy justifications for the Australian federation (Moran 2011; Brumby and Galligan 2015): a laboratory for natural experiments in policy that enhance opportunities for cross-jurisdictional learning through comparison of different approaches to related problems. There are some cases of partial, OMC-type experiments available in the contemporary history of Australian federalism; for example, Parkin (1988) analysed interrelations between, and diversity within, Commonwealth-state housing agreements, where there were compromised but shared goals alongside substantial local discretion in implementation. However, it is the December 2008 IGA on new fiscal federal arrangements that marks the critical juncture in an OMC trend within Australian federalism.

This intergovernmental fiscal reform is significant in both its scale and its awkwardness for the centralisation narrative of Australian federalism. The 2008 IGA is designed to reduce Commonwealth Government prescriptions on service delivery by the states, and allow them increased flexibility in policymaking with the corollary of policy diversity. The cornerstone is a major reduction in the number of specific purpose payments (SPPs) to the states, from over 90 to five. These are supported by national agreements, which establish the broad policy objectives and an extensive performance and assessment framework, publicly reported and administered by the COAG Reform Council.

National agreements need to be distinguished from the national partnership agreements, included in the same IGA. The latter are time limited and involve fiscal incentives via payments to the states that are linked with specific reform activities or projects (O'Loughlin 2011). The national agreements are salient as the nascent OMC feature in Australian public policy; they set out the objectives, outcomes, outputs 
and performance indicators by sector, which have been agreed in advance between all jurisdictions. They do not include financial or other resource input controls on policy by the state and territory governments, and there is no provision for national SPPs to be withheld in the case of a jurisdiction not meeting a performance benchmark specified in a national agreement. The five SPPs give block grants by sector, and the states and territories have full budget discretion to allocate funds within that sector to achieve the agreed objectives for that sector. Importantly, the policy areas covered by the national agreements are at the core of the microfoundations of productivity: education, skills and workforce development, health care, affordable housing and disability services.

The 2008 IGA gave the now defunct COAG Reform Council significant responsibilities for performance assessment and reporting under national agreements. The COAG Reform Council provided annual reports to COAG on each of the agreements based on a comparative analysis of governing performance against the established benchmarks for progress in reform and improvements in service delivery. In November 2013, the COAG Reform Council published a five-year report card on the 2008 IGA on fiscal federal reform, which, in broad terms, shows measured progress on the ambitious goals set in 2008 to have been mixed (Brumby 2013). Of particular relevance to this chapter, the COAG Reform Council (2013) report also provides analysis of the actual process of COAG reform to supplement the existing large number of performance reports in the key areas of the 2008 agreement. Among other things, this process analysis highlights weaknesses in implementation, the need for better performance data and agreement on higher-quality indicators, as well as observing the well-known tendency of governments making or inheriting long-term commitments to move away from outcome measures and lose sight of program logic, reverting instead to input or activity measures.

It is premature to infer any firm lessons on changes to multi-level policy capacity in Australia from the OMC tendency in the 2008 IGA. This is because the OMC is designed as a learning process where standard policy evaluation logic only applies imperfectly; although Moran (2011) expresses some doubts about whether the performance management systems at the state level have eventuated to match national agreements entered into, sustained comparative and longitudinal analysis is required for more concrete conclusions. At this stage, and for the purposes of this chapter, the concept of the $\mathrm{OMC}$ is offered as a potential way of diagnosing a changing dynamic in Australian federalism. This conceptualisation of 
the 2008 IGA may help inform studies of its effects on policy orientation and thinking across, and between, levels in the Australian federation; the nature of the analytical work undertaken on benchmarking, peer review, monitoring and iterative redesign; and whether there is evidence of crossjurisdictional policy learning.

In EU terms, the OMC has been established as a means of extending EU involvement in a range of policy domains where it has no formal or legal competence, but simultaneously protecting member-states' authority in those areas. In the Australian case of concurrent constitutional powers and strong interdependence in terms of policy capacity, the 2008 IGA reveals the potential of OMC to substitute in some cases for detailed COAG agreements on a uniform, national policy framework. Despite the fact that the OMC is not legally binding, the EU and many scholars regard the $\mathrm{OMC}$ as effective in achieving policy coordination in certain cases (e.g. Hodson and Maher 2001). There is burgeoning research in EU studies on the conditions for a 'soft' and non-binding governance method to be effective. In particular, attempts are underway to identify the mechanisms to explain why member-state governments might pursue policies aimed at OMC objectives even though they are not legally obliged to do so and are not threatened by sanctions other than 'naming and shaming' by the EU Commission (Sabel and Zeitlin 2007; Zeitlin and Sabel 2009).

There are sceptics on the effectiveness of the OMC compared to "hard law' EU policy and suggestions that the OMC cannot influence national policymaking due to its non-bindingness and lack of sanctions (e.g. Chalmers and Lodge 2003). As discussed above, however, the MLG term has been freighted to label circumstances in which a hierarchical mode of policy-making is ineffective: where there is a substantial implementation gap between central edicts and control of policy on the ground. Softness is likely to be more successful than hardness in such circumstances, particularly if different states in Australia disagree strongly about the policy instruments and settings appropriate to their social and economic conditions or want to retain their authority over a particular policy area.

\section{Trust-building in the Australian federation}

MLG processes are, by definition, non-hierarchical and relatively informal; it is the capacity to influence and persuade rather than command and control that is central in bringing about problem-solving as the dominant 
mode of interaction. In particular, for the OMC to be effective, tolerance of diversity in approach and performance is essential. Trust is an essential ingredient in this; without it, differentials are liable to be exploited politically, producing strong centralising pressures for territorial uniformity. This reveals that MLG in the EU is founded to an extent on the socialisation of actors involved, and its relative success or failure in any domain is a function of the degree to which this socialisation can be captured in enduring institutions - formal and informal - over time. We might hypothesise that this is more easily found in the Australian context, with only nine governments involved, but we know little about this. This is the challenge to academic study of Australian federalism: to understand systematically the emergence of intergovernmental trust in particular policy sectors and draw robust lessons of how this facilitates a problem-solving orientation.

There are two basic ways to understand the role of trust in the interaction of representatives from multiple levels. The first is in assisting with problem-solving amongst self-interested, rational actors; the alternative is in developing commitments towards a shared view of the problem and/ or obligations towards certain normative schemes. They are not mutually exclusive and, in practice, we may observe both roles coexisting.

Under the first approach, it is the system of negative and positive incentives to MLG actors that will determine how successfully the problem-solving mode of governance operates in achieving collective ends. The basic motivations behind compliance with MLG 'soft' demands are the benefits that actors may gain from the acceptance of these demands and/or the avoidance of the costs of non-adoption. Repeated interaction helps build high trust in the commitments of others to certain action and, following the insights from repeated, non-cooperative game theory, a nonhierarchical equilibrium may be achieved. Actual practice in Australia can, however, make such an analysis appear exclusively academic: the turnover and churn of political leaders and senior bureaucrats presents the question of how trust and a shared problem-solving commitment can endure and become institutionalised. This is again an area where we lack systematic data on what has worked in the past in Australia.

In the second analytical avenue, shifting the normative considerations of appropriateness of the divergent demands will influence the scope of possible policy coordination. This is where deliberation leads to policy change that coordination implies must be considered as correct and 
legitimate by relevant decision-makers at each level in order to be adopted and implemented. Socialisation contributes to high trust through regular personal and official contacts, and its possible effect in terms of a degree of normative convergence over time about 'what ought to be done' is enforced by norms of shame and loyalty/kinship. In this problemsolving mode, the reliance is not on high-powered incentives to policy action but rather the use of high trust to support norms that persuade, shame or otherwise encourage policy actors into accepting the required policy change.

\section{Conclusion}

MLG in the Australian context moves us away from simply viewing Commonwealth-state relations as a zero sum game of formal authority and fiscal power to considering the possibility of enhanced policy capacity through experimentation and innovation in multi-level interactions. It encourages a research focus on the relationship between Type I and Type II MLG in the Australian federation, notably the extent to which a shared problem-solving approach can be achieved in a particular policy sector. The OMC is a distinctive mode of MLG Type II, developed in the EU to exploit the potential for within-Treaty innovation, given the ongoing constitutional problems of European integration; problems that, far from perfectly analogous, bear a strong resemblance to debates about coordinate federalism in Australia. This chapter has presented the OMC not as a soft, second-best option to hard legislation or commandand-control authority but rather as a prominent Type II MLG; a nonbinding mechanism for policy coordination appropriate to many contemporary governance challenges. The 2008 IGA exhibits certain OMC characteristics: in the national agreements, the policy design and implementation functions remain at state level and diversity is encouraged. When the consequences of structural change in the Australian economy are uncertain and widespread but presenting territorially diverse policy challenges, an OMC approach to multi-level policy coordination is liable to be more effective than a uniform standardised policy framework imposed from the centre. 


\section{References}

Abbott, T. (2014). Speech to Sir Henry Parkes Commemorative Dinner, Tenterfield, 25 October 2014, ahha.asn.au/sites/default/files/docs/ policy-issue/sir_henry_parkes_commemorative_dinner_speech_ prime_minister.pdf [Accessed 29/06/2017].

Anderson, G.M. (2008). The Council of Australian Governments: A new institution of governance for Australia's conditional federalism. University of New South Wales Law Journal 31(2): 493-508.

Australian Government (2015). COAG and Federal Financial Relations, Reform of the Federation White Paper. Issue Paper 5. Department of the Prime Minister and Cabinet, Australian Government, Canberra.

Brenner, N. (2004). New State Spaces: Urban Governance and the Rescaling of Statehood. Oxford University Press, Oxford and New York. doi.org/10.1093/acprof:oso/9780199270057.001.0001

Brenner N., Peck J. \& Theodore, N. (2010). Variegated Neoliberalization: Geographies, modalities, pathways. Global Networks 10(2): 1-41. doi.org/10.1111/j.1471-0374.2009.00277.x

Brown, A. (2007). Federalism, Regionalism And The Reshaping Of Australian Governance. In: Brown, A.J. \& Bellamy, J. (eds) Federalism and Regionalism in Australia: New Approaches, New Institutions? ANU E Press, Canberra, pp. 11-33.

Brumby, J. (2009). Does Federalism Work? In: Wanna, J. (ed.) Critical Reflections on Australian Public Policy. ANU E Press, Canberra, epress. anu.edu.au/anzsog/critical/pdf/ch02.pdf [Accessed 18/07/2008].

- (2013). Reform or Perish: 5 Years of National Reform. Speech to National Press Club, November 2013.

Brumby, J. \& Galligan, B. (2015). The Federalism Debate. Australian Journal of Public Administration, 74(1): 82-92. doi.org/10.1111/14678500.12132

Campbell, J.L. (2004). Institutional Change and Globalization. Princeton University Press. 
Carroll, P. \& Head, B. (2010). Regulatory Reform and the Management of Intergovernmental Relations in Australia. Australian Journal of Political Science, 45(3): 407-24. doi.org/10.1080/10361146.2010 .509310

CEDA (2014). A Federation for the 21st Century. Committee for the Economic Development of Australia, Melbourne.

Chalmers, D. \& Lodge, M. (2003). The Open Method Of Co-Ordination And The European Welfare State. CARR Discussion Chapters, DP 11, LSE, London.

COAG Reform Council (2013). Lessons For Federal Reform: COAG Reform Agenda 2008-2013. Council of Australian Governments.

Committee of the Regions (2009). White Chapter On Multi-level Governance, CdR 89/2009. European Union, Brussels.

Commonwealth of Australia (2015). Competition Policy Review. Final Report. March 2015. Australian Government, Canberra.

Cormann, M. (2015). Smaller, More Rational Government. Minister of Finance Ministerial Paper, Commonwealth of Australia, Canberra.

Eisenschitz A. \& Gough, J. (1996). The Contradictions Of NeoKeynesian Local Economic Strategies. Review of International Political Economy, 3(3): 434-58. doi.org/10.1080/09692299608434364

European Commission (2001). European Governance: A White Chapter. COM (2001) 428, EU Commission, Brussels.

Fenna, A. (2009). Federalism. In: Rhodes, R.A.W. (ed.) The Australian Study of Politics. Palgrave Macmillan, Houndsmills.

- - (2012). Centralising Dynamics in Australian Federalism. Australian Journal of Politics and History, 58(4): 580-90. doi.org/10.1111/j.14678497.2012.01654.x

Gleeson, B. (2003). Learning About Regionalism from Europe: 'Economic normalisation' and beyond, Australian Geographical Studies, 41(3): 221-36. doi.org/10.1046/j.1467-8470.2003.00231.x 
Head, B. (2007). Taking Subsidiarity Seriously: What role for the states? In: Brown, A.J. \& Bellamy, J. (eds) Federalism and Regionalism in Australia: New Approaches, New Institutions? ANU E Press, Canberra, pp. 155-70.

Hodson, D. \& Maher, I. (2001). The Open Method of Coordination as a New Mode of Governance: The case of soft economic policy coordination. Journal of Common Market Studies, 39(4): 719-46. doi.org/10.1111/1468-5965.00328

Hollander, R. \& Patapan, H. (2007). Pragmatic Federalism: Australian federalism from Hawke to Howard. Australian Journal of Public Administration, 66(3): 280-97. doi.org/10.1111/j.14678500.2007.00542.x

Hooghe, L. \& Marks, G. (2001). Types of Multi-level Governance. European Integration Online Chapters (EIoP) 5(11), eiop.or.at/eiop/ pdf/2001-011.pdf [Accessed: 14/01/2014].

Keating, M. \& Wanna, J. (2000). Remaking Federalism? In: Keating, M., Wanna, J. \& Weller, P. (eds) Institutions on the Edge? Allen \& Unwin, Sydney, pp. 126-55.

Kelly, P. (2010). Mission Is To Manage Politics Of Prosperity. Australian, 24 November 2010.

Kildea, P. \& Lynch, A. (2010). Entrenching 'Cooperative Federalism': Is it Time to Formalise COAG's Place in the Australian Federation? Conference of the Australian Political Studies Association, University of Melbourne, Melbourne, 28 September 2010.

Krugman, P. (1998). What's New About The New Economic Geography? Oxford Review of Economic Policy, 14(2): 7-17. doi.org/10.1093/ oxrep/14.2.7

Marks, G. (1993). Structural Policy and Multilevel Governance in the EC. In: Cafruny, A. \& Rosenthal, G. (eds) The State of the European Community: Volume 2. Lynne Rienner, Boulder CO, pp. 391-410.

Mathews, R.L. (ed.) (1977). State And Local Taxation. Centre for Research on Federal Financial Relations, Australian National University Press, Canberra. 
. (1982). Federalism in Retreat: The Abandonment of Tax Sharing and Fiscal Equalisation. Australian National University Press, Canberra.

Moran, T. (2011). An Effective Federation in Delivering Australia's Next Wave of Reform. Address to the EIDOS Institute, 8 June 2011.

Morgan, B. (2003). The Economisation of Politics: Meta-regulation as a form of nonjudicial legality. Social and Legal Studies, 12(4): 489-523. doi.org/10.1177/0964663903012004004

O'Loughlin, M. (2011). Collaborative Reform: Lessons from the COAG Reform Council, 2008-2010. In: Lindquist, E., Vincent, S. \& Wanna, J. (eds) Delivering Policy Reform Anchoring Significant Reforms in Turbulent Times, ANU E Press, Canberra, pp. 91-8.

Painter, M. (1998). Collaborative Federalism. Cambridge University Press, Melbourne. doi.org/10.1017/CBO9780511552236

- - (2001). Multi-level Governance and the Emergence of Collaborative Federal Institutions in Australia. Policy \& Politics, 29(2): 137-50. doi. org/10.1332/0305573012501260

Parkin, A. (1988). Housing Policy. In: Galligan, B. (ed.) Comparative State Policies. Longman Cheshire, Melbourne, pp. 249-68.

Parkin, A. \& Anderson, G. (2007). The Howard Government, Regulatory Federalism and the Transformation of Commonwealth-State Relations. Australian Journal of Political Science, 42(2): 295-314. doi.org/10.1080/10361140701320034

Peck J. \& Theodore, N. (2007). Variegated Capitalism. Progress in Human Geography, 31(6): 731-72. doi.org/10.1177/0309132507083505

- - (2010). Labor Markets From The Bottom Up. In: McGrathChamp, S., Herod, A. \& Rainnie, A. (eds) Handbook Of Employment and Society: Working Space. Edward Elgar, Cheltenham, pp. 87-105. doi.org/10.4337/9781849806305.00014

Peters, G. \& Pierre, J. (2004). Multi-level Governance and Democracy: A 'Faustian bargain'. In: Bache, I. \& Flinders, M. (eds) Multilevel Governance. Oxford University Press, pp. 75-90. doi.org/ 10.1093/0199259259.003.0005 
Porter, M.E. (1998). The Competitive Advantage of Nations. 2nd edn, Free Press, New York. doi.org/10.1007/978-1-349-14865-3

Sabel, C.F. \& Zeitlin, J. (2007). Learning from Difference: The New Architecture of Experimentalist Governance in the European Union. European Governance Chapters (EUROGOV) No. C-07-02.

Sawer, G. (1969). Modern Federalism. Watts, London.

Scharpf, F.W. (1988). The Joint-Decision Trap. Lessons From German Federalism and European Integration. Public Administration, 66(2): 239-78. doi.org/10.1111/j.1467-9299.1988.tb00694.x

Senate Committee Report (2011). Reform of the Australian Federation. Commonwealth of Australia, Parliament House, Canberra.

Stein, M. \& Turkewitsch, L. (2008). The Concept of Multi-level Governance in Studies of Federalism. International Political Science Association (IPSA) International Conference International Political Science: New Theoretical and Regional Perspectives, Concordia University, Montréal, Canada, pp. 184-202.

Zeitlin, J. \& Sabel, C.F. (eds) (2009). Experimentalist Governance in the European Union: Towards A New Architecture. Oxford University Press, Oxford and New York. 
This text is taken from Multi-level Governance: Conceptual challenges and case studies from Australia, edited by Katherine A. Daniell and Adrian Kay, published 2017 by ANU Press, The Australian National University, Canberra, Australia.

dx.doi.org/10.22459/MG.11.2017.02 